\title{
Rapid Screening of Protein Profiles of Human Breast Cancer Cell Lines Using Non-porous Reversed-phase High Performance Liquid Chromatography Separation with Matrix- assisted Laser Desorption/Ionization Time-of- flight Mass Spectral Analysis
}

\author{
Bathsheba E. Chong ${ }^{1}$, David M. Lubman ${ }^{1}$, Fred R. Miller ${ }^{2}$ and Allen J. Rosenspire ${ }^{3}$ \\ ${ }^{1}$ Department of Chemistry, The University of Michigan, Ann Arbor, MI 48109-1055, USA \\ ${ }^{2}$ Karmanos Cancer Institute, The Detroit Medical Center, Detroit, MI 48201, USA \\ ${ }^{3}$ Department of Biological Sciences, The Wayne State University, Detroit, MI 48202, USA
}

SPONSOR REFEREE: Dr. Jackson Lay, Department of Health and Human Services, National Center for Toxological Research, 3900 NCTR Drive, Jefferson, AR 72079, USA

\begin{abstract}
Non-porous reversed-phase (NP-RP) HPLC has been used to rapidly generate protein profiles of whole cell lysates of human breast cancer cell lines. The non-porous packing material used was silica coated with $\mathrm{C18}$, which provided rapid separation with high collection efficiency of proteins from cell lysates. This method was used to study the differences in protein profiles among normal cells and fully malignant cells that share a common genetic background. The highly expressed proteins in each cell type were separated and collected in the liquid state where they were analyzed by matrix-assisted laser desorption/ionization time-of-flight mass spectrometry (MALDI-TOFMS) to obtain the molecular weight of the proteins. The protein fractions were then subjected to tryptic digestion and analyzed by pulsed delay extraction (PDE)-MALDI-TOFMS to obtain the peptide maps. The expressed proteins were identified based upon the molecular weight and peptide map using database-searching procedures. It is shown that key cancer-related proteins can be detected and identified which may be potentially used as biomarkers for cancer detection. Copyright (C) 1999 John Wiley \& Sons, Ltd.
\end{abstract}

Received 16 July 1999; Accepted 19 July 1999

The transformation of cells into malignant cancer depends on genetic mutations. These mutations lead to the activation of cellular oncogenes that take over the processes in the cell transforming it into an entity that continues to survive and proliferate. In turn this transformed cell may undergo further mutations and develop into a fully malignant tumor cell. Although these changes in the cell occur at the DNA level, they must ultimately be expressed in terms of the protein content of the cell. Small mutations in the DNA may manifest themselves as large changes in the resulting protein cascades that control various functions in the cell. Many of the mutations that occur in the DNA result in posttranslational changes in the proteins that cannot be predicted from the DNA information. Thus, changes in the cell that result from malignant transformation are often best followed by monitoring changes in the protein expression that results.

The traditional method of studying changes in cellular protein expression has been two-dimensional polyacrylamide gel electrophoresis (2-D PAGE). ${ }^{1-5}$ More recently, several liquid phase based techniques have been developed

\footnotetext{
*Correspondence to: D. M. Lubman, Department of Chemistry, The University of Michigan, Ann Arbor, MI 48109-1055, USA

Contract/grant sponsor: National Science Foundation; Contract/grant number: DEB9120006.

Contract/grant sponsor: National Institutes of Health; Contract/grant number: ROIGM49500.
}

for the separation of proteins. ${ }^{6-16}$ These methods include the use of liquid chromatography, which allows a means of separating and isolating proteins in the liquid phase. ${ }^{6-16}$ Reversed-phase (RP) C18 column separations have been used to separate proteins from whole cell lysates of bacterial cells ${ }^{16}$ and from human lymphocyte nuclei. ${ }^{12}$ The use of such chromatographic separations allows the rapid screening of proteins from whole cell lysates on a time scale of less than an hour as compared with the extended time required running a 2-D gel. The use of liquid phase separations also provides proteins in the liquid phase that can be more easily analyzed by mass spectrometry.

In recent work, non-porous reversed-phase (NP-RP) high performance liquid chromatography (HPLC) has been used for separations of whole cell lysates of bacterial ${ }^{16}$ cells and human erythroleukemia (HEL) cells. ${ }^{10}$ The use of these non-porous, C18 coated, silica-based packing materials has been shown to provide important advantages in the separations of protein mixtures compared with the porous columns. The NP-RP-HPLC separations showed excellent resolution for separations of proteins in less time than the porous columns. Separations of whole cell lysates using the non-porous columns can be performed in typically 15-30 minutes. The use of non-porous packing avoids the problem of proteins sticking inside the pores of porous materials and thus considerably improves the resolution and protein recovery. 
In this work, we use NP-RP-HPLC to rapidly separate proteins from whole cell lysates of breast cancer cell lines. The MCF-10 cell lines examined in this work have been developed based upon spontaneous immortalization of breast epithelial cells obtained from a patient with fibrocystic disease. ${ }^{17}$ Since all cell lines examined in this work were derived from a single patient, irrelevant differences in gene expression should be minimized. The NP-RP-HPLC method is thus used to rapidly screen the proteins from whole cell lysates of two malignant cell lines and one normal (immortalized) cell line. The method is used to search for elevated levels of proteins or the appearance of new proteins in the malignant cells as compared with the normal cells. It is shown that several key cancer-related proteins, including $\mathrm{p} 53,{ }^{18-26} \mathrm{c}-\mathrm{src},{ }^{27-29} \mathrm{c}-\mathrm{myc},{ }^{30-32}$ and hras, ${ }^{30,33}$ are observed in the malignant cell lines at highly elevated levels compared with the normal cells. In addition, the protein-containing liquid can be collected following separation and analyzed after tryptic digestion using MALDI-TOFMS. The resulting peptide map can be entered into the MS-Fit of the Protein Prospector Database for identification. It is demonstrated that NP-RP-HPLC of whole cell lysates with analyses by MALDI-TOFMS may serve as a powerful tool for rapid monitoring of changes in oncogene expression in human breast carcinoma.

\section{EXPERIMENTAL}

\section{Chemicals}

The chemicals involved in this study were used without prior purification. Acetone (HPLC grade) was obtained from Fisher (Fair Lawn, NJ, USA). Acetonitrile, guanidine hydrochloride (gu-HCl), $\alpha$-cyano-4-hydroxycinnamic acid $(\alpha-\mathrm{CHCA})$, trifluoroacetic acid (TFA) and octyl glucopyranoside (OCG) were from Aldrich (Milwaukee, WI, USA). Trypsin was acquired from Promega (Madison, WI, USA). Distilled and deionized water was obtained from a Milli-Q reagent grade purification system from Millipore (Bedford, MA, USA). The nitrocellulose (NC) used, Immobilon-NC Pure, was also from Millipore.

\section{Cell cultures}

The MCF-10 cell samples used in these experiments originated by spontaneous immortalization of breast epithelial cells from a fibrocystic patient. ${ }^{17}$ Immortalized MCF-10A cells are not transformed and share many properties with normal breast epithelial cells. Fully malignant, metastatic variants, MCF-10 Cala and Cald, were also derived from the same source. ${ }^{34}$ Cells were maintained in a humidified $\mathrm{CO}_{2}$ incubator at $37^{\circ} \mathrm{C}$ and adherent cells harvested in log phase $(\sim 70-80 \%$ confluence). In order to harvest the cells, the growth media was aspirated and the cells gently washed with PBS, prior to scraping with a rubber policeman. The cells were immediately frozen $\left(-80^{\circ} \mathrm{C}\right)$ upon removal from the tissue culture dishes.

\section{Matrix, substrate and sample preparation}

$\alpha$-CHCA was the matrix used in these experiments. For MALDI analysis, the matrix was prepared as a saturated solution in a 4:1 ratio of acetone to Milli-Q water containing 0.1 to $0.5 \%$ TFA. Before applying the sample solution to the steel probe tip, $2 \mu \mathrm{L}$ of nitrocellulose $(\mathrm{NC} ; \sim 10 \mathrm{mg} / \mathrm{mL}$ in acetone) were applied to the tip and allowed to air dry followed by $3-5 \mu \mathrm{L}$ of sample solution, which were also allowed to air dry. The final step involved the addition of $4 \mu \mathrm{L}$ of matrix solution onto the probe tip that were also air dried.

The cell pellets were lysed in $200 \mu \mathrm{L}$ of $50 \mathrm{mM}$ Tris buffer ( $\sim \mathrm{pH} 7), 6 \mathrm{M}$ gu-HCl and 5-10 mM OCG. This mixture was vortexed for $30 \mathrm{~s}$ and stored overnight at $-20^{\circ} \mathrm{C}$. Subsequently, the lysate was fractionated by centrifugation in an Eppendorf centrifuge at $16500 \mathrm{rpm}$ for $20 \mathrm{~min}$. In order to remove as much particulate and cell debris as possible, the soluble portion was centrifuged at $16500 \mathrm{rpm}$ for another $10 \mathrm{~min}$. The most reproducible results were observed when the soluble portion was analyzed within $24 \mathrm{~h}$.

Using a Speed-Vac the total volume of the NP-RP-HPLC collected fractions was reduced to $10-20 \mu \mathrm{L}$ in order to remove the acetonitrile and TFA. Then $10 \mu \mathrm{L}$ of $50 \mathrm{mM}$ ammonium bicarbonate were added to each fraction and it was vortexed. Finally, $2 \mu \mathrm{L}$ of the sequencing grade modified trypsin $(0.5 \mathrm{mg} / \mathrm{mL})$ were added to the fractions. Again the mixtures were vortexed and incubated at $37^{\circ} \mathrm{C}$ for $24 \mathrm{~h}$.

After tryptic digestion, the resulting peptides were subjected to PDE-MALDI analysis to obtain peptide maps. In the PDE-MALDI analysis, one part of the saturated matrix solution was diluted 10 fold, i.e. $9 \mu \mathrm{L}$ of acetone $(0.1$ to $0.5 \%$ TFA) were added to $1 \mu \mathrm{L}$ of matrix solution. Then $2 \mu \mathrm{L}$ of this diluted matrix solution were added directly to the probe tip. To improve the PDE-MALDI mass spectra, the peptide solution generated by tryptic digestion was reacidified by adding 2 to $5 \mu \mathrm{L}$ of Milli-Q water (0.1\% TFA). Then $8 \mu \mathrm{L}$ of this acidified digest solution were mixed with $1 \mu \mathrm{L}$ of the diluted matrix solution. This mixture was vortexed, and $3 \mu \mathrm{L}$ were applied to the dried matrix layer. When this layer was dry, another $3 \mu \mathrm{L}$ were added and dried. This procedure was repeated several times.

\section{NP-RP-HPLC analysis}

A Beckman (Fullerton, CA, USA) System Gold ${ }^{\circledR}$ HPLC was utilized for this work. The pump (Model 128) has a gradient solvent delivery module with built-in system controller. The detector is a programmable detector module (Model 166) with an analytical flow cell. The deuterium lamp provides a wide range of detection from 190 to $700 \mathrm{~nm}$. All separations in this work were monitored at $214 \mathrm{~nm}$. The column was provided by MICRA (Northbrook, IL, USA). It contained non-porous silica bead packing material of $1.5 \mu \mathrm{m}$ particle diameter coated with $\mathrm{C} 18$. The dimension of the column was $4.6 \times 33 \mathrm{~mm}$ where the widebore column was necessary to collect an adequate amount of material and the short length allowed for rapid separations on the order of minutes. The RP-HPLC separations of proteins in the tumor cell lysate was performed via gradient elution of two solvents (solvent A: Milli-Q water with $0.1 \%$ TFA; solvent B: acetonitrile with $0.1 \%$ TFA) with a flow rate of $1 \mathrm{~mL} / \mathrm{min}$ where the temperature of the non-porous column was maintained at $60^{\circ} \mathrm{C}$ in a Timberline (Boulder, $\mathrm{CO}$, USA) column heater. The gradient profile used for solvent B was generally as follows: $0 \%$ for $1.5 \mathrm{~min}$; 0 to 10 $\%$ in $2 \mathrm{~min} ; 10$ to $60 \%$ in $25 \mathrm{~min} ; 60$ to $80 \%$ in $5 \mathrm{~min}$; 80 to $100 \%$ in $1 \mathrm{~min} ; 100 \%$ for $2 \mathrm{~min} ; 100$ to $0 \%$ in $1 \mathrm{~min}$. In order to obtain a reproducible separation profile, the sample was 'conditioned' to the column environment by mixing the 

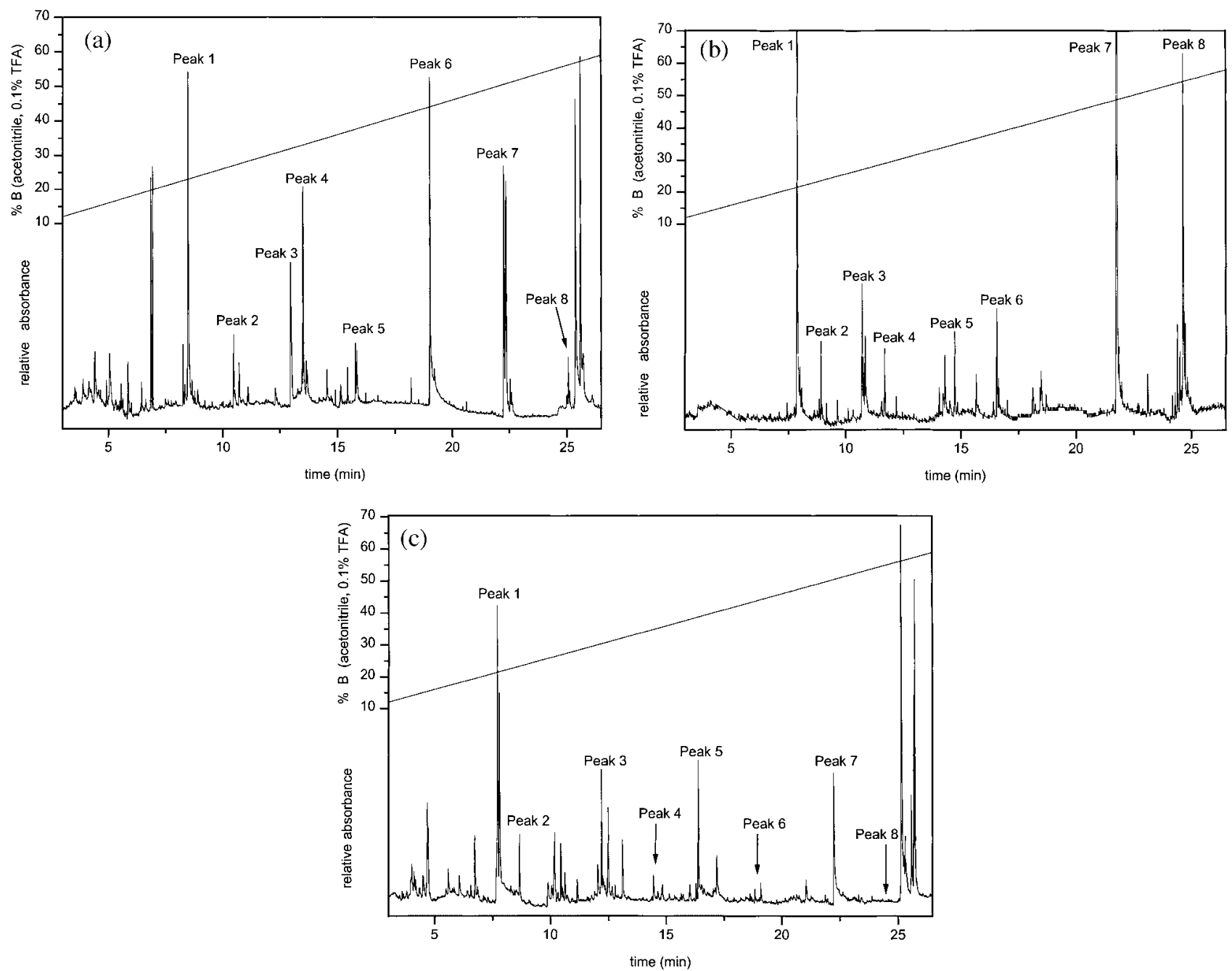

Figure 1. (a) NP-RP-HPLC protein profile: malignant human breast cell lysate (calaCL1). (b) NP-RP-HPLC protein profile: malignant human breast cell lysate (caldCL1). (c) NP-RP-HPLC protein profile: normal (immortalized) human breast cell lysate (10A).

sample with an equivalent amount of water $(0.1 \%$ TFA), or a 1:1 ratio. This acidifying step was performed prior to sample injection. Each injection contained an average of $50 \mu \mathrm{g}$ of protein. The fractions collected were subsequently subjected to MALDI analysis to size the protein masses. Each of the peaks contained an average of $\sim 1-5 \mu \mathrm{g}$ available for analysis after collection. The fractions were then digested by trypsin before undergoing PDE-MALDI analysis to obtain their peptide maps.

\section{MALDI mass spectral analyses}

The TOF mass spectrometer employed in these studies was a modified Wiley-McLaren design with a four-plate acceleration stage. $^{35}$ It was capable of high voltage acceleration up to $\pm 20 \mathrm{kV}$ (R. M. Jordan Co., Grass Valley, CA, USA). The laser source used to produce MALDI was a Minilite ${ }^{\circledR} 10 \mathrm{~Hz} \mathrm{Nd}$ :YAG laser system (Continuum, Santa Clara, CA, USA). All mass spectra were obtained using $355 \mathrm{~nm}$ radiation. The laser power density was estimated at $\sim 5 \times 10^{6}$ to $1 \times 10^{7} \mathrm{~W} / \mathrm{cm}^{2}$. The detector was a triple microchannel plate (MCP) detector (R. M. Jordan Co.) which adapted a $\mathrm{CuBe}$ conversion dynode with postacceleration (PA) capability up to $\pm 12 \mathrm{kV}^{36}$ in front of the MCP. The total ion acceleration across the TOF device may thus be $>30 \mathrm{kV}$. The PA stage enhances the detection of heavy species, but at the expense of resolution. In addition, pulsed delayed extraction (PDE) as described in previous studies ${ }^{37-41}$ could be used to enhance the resolution for the analysis of the tryptic digests. The $1-\mathrm{m}$ long flight tube was pumped to a base pressure of $8 \times 10^{-7}$ to $1 \times 10^{-6}$ Torr by a diffusion pump (Varian Inc., Lexington, MA, USA). Data was recorded using a LeCroy 9310AM (400 MHz) digital oscilloscope (LeCroy Corp., Chestnut Ridge, NY, USA) and was processed on a Gateway 586 computer.

\section{Database-searching procedure for protein identification}

The MS-Fit sequence database located in the Protein Prospector program was used for protein identification by entering the peptide masses generated by tryptic digestion. The program is available on the Internet. ${ }^{42}$ Subsequently, other relevant parameters such as protein species, molecular weight and pI range are also entered in order to narrow down the search. In this case, Homo sapiens was chosen as the species. Since these proteins were obtained from HPLC, no $\mathrm{pI}$ information was available. Thus, the $\mathrm{pI}$ range was set between 3 and 10. The range of molecular weight values for each search was determined by MALDI analysis. The 


\begin{tabular}{|c|c|c|c|}
\hline Peak & Protein name & Mol. wt. (kDa) & Accession number \\
\hline 1 & Transforming protein P21 (c-h-ras) & 21.3 & P01112 \\
\hline \multirow[t]{2}{*}{3} & Prohibition & 29.8 & P35232 \\
\hline & C-myc promoter protein & 37.0 & P22712 \\
\hline \multirow[t]{2}{*}{4} & L-myc-1 proto-oncogene protein & 40.3 & $\mathrm{P} 12524$ \\
\hline & JNK activating kinase 1 & 44.2 & P45985 \\
\hline 5 & P53 regulated PA26-73 nuclear protein & 49.6 & AADO4811 \\
\hline 6 & Breast epithelial antigen BA46 & 43.1 & Q08431 \\
\hline 7 & Phosphoprotein p53 & 43.6 & P04637 \\
\hline 8 & Proto-oncogene tyrosine kinase SRC (c-src) & 59.8 & P12931 \\
\hline
\end{tabular}

tolerance for the search of peptides against the database was set between 5 and 30 Da.

\section{RESULTS AND DISCUSSION}

Figures 1(a)-(c) show the protein profiles of whole cell lysates of the MCF-10 based breast epithelial cell lines for two different cell lysates of malignant cell lines (Figs 1(a), (b)) and for the normal immortalized cell line (Fig. 1(c)). The gradient (between 10 and $60 \%$ B) is shown in each figure where the expressed peaks of interest are labeled based upon the percent acetonitrile as they eluted. Since different gradients were run in each case, the time axis cannot be used as a means of comparison in these separations. Each of the labeled peaks was collected as a fraction in the liquid state and part of the fraction was used to obtain the molecular weight by MALDI-TOFMS. The remainder was subjected to tryptic digestion and the resulting tryptic map was entered into the MS-Fit Database to identify these proteins.

The protein profiles generated by NP-RP-HPLC clearly show large differences in the proteins expressed in the malignant cells (Figs 1(a) and (b)) as compared with the normal cells (Fig. 1(c)). The proteins identified using tryptic digestion are listed in Table 1, while the differences in peak expression level (or relative peak absorbance) between the two malignant cell lines and normal cell line are tabulated in Table 2. The distinctive feature in the malignant cancer cell

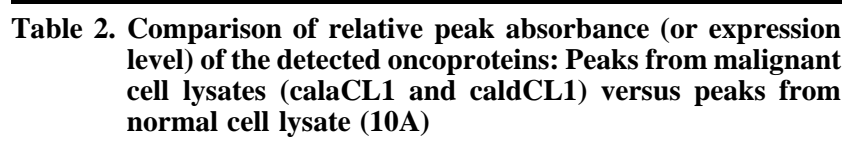

$\begin{array}{lrc}\text { Peak } & \text { calaCL1 vs. } 10 \mathrm{~A}( \pm \%) & \text { caldCL1 vs. } 10 \mathrm{~A}( \pm \%) \\ 1 & +7 & +19 \\ 2 & \text { similar } & -12 \\ 3 & \text { similar } & -29 \\ 4 & +800 & +100 \\ 5 & -61 & -66 \\ 6 & +2100 & +400 \\ 7 & \text { similar } & +64 \\ 8 & +1300 & +6300\end{array}$

Note: $(+)$ means more highly expressed than 10A, (-) means less expressed than 10A. 'Similar' means that the expression level is similar in both the malignant and normal cell lysates. The relative peak absorbance was calculated using the following formula:

expression level (malignant cell-normal cell) expression level of normal cell lines is the overexpressed presence of p53 (peak 7) and proto-oncogene tyrosine kinase SRC (c-src) (peak 8) as compared with normal cells. In addition, other proteins often associated with cancer progression such as c-myc, hras and various related proteins are also observed. In particular, the p53 peak serves as a distinctive marker of the cancer cells. It is known that p53 is expressed at high levels in a number of tumor types and its overexpression is often an indicator of unfavorable prognosis for several cancers including breast cancer. ${ }^{43-45}$ As a key tumor suppressor protein, p53 plays an important role in regulating the cell cycle and normal cell growth. ${ }^{18-20}$ The loss of p53 function due to a variety of mutations in different types of cancer is believed to be a significant factor in the unrestrained growth of cancer cells. All normal cells have low levels of p53. However, mutations in p53 can increase its half-life from 20 minutes to several hours, thus resulting in accumulation of p53 in cancer cells. ${ }^{23}$ The levels of p53 detected in these breast cancer cell lines clearly dominate the protein profiles under $80 \mathrm{kDa}$. It is not known at present from the MALDITOFMS peptide map data whether the p53 is the wild or mutant form. In order to determine the presence of either point mutations or phosphorylations, more detailed sequencing procedures will be required.

In addition, c-src is an oncoprotein of the kinase type that is observed in both the malignant cancer cell lines (Figs 1(a) and (b)) but is not observed at comparable levels in the normal cell protein profile of Fig. 1(c). Mutations of src are believed to be involved in cell transformation and its overexpression results from the phosphorylation of target proteins. ${ }^{27-29}$ This transformation may be due to the increased level of phosphorylation, or a change in the site of phosphorylation may be involved. Moreover, src is able to phosphorylate itself and the state of phosphorylation of src may be important in its transforming activity. The MALDI peptide map in this work did not provide sufficient information to determine where the src was mutated. Nevertheless, the presence of c-src in the cancer cell protein profiles in this work makes it a potential marker for cancer detection.

An important aspect of Figs 1(a) and (b) is that there are distinct differences in protein expression for the two malignant cancer cell lines, even though they were developed from a common genetic background. In Fig. 1(a), in the calaCL1 cell line, there are strong peaks for the L-myc proto-oncogene protein and the c-myc promoter protein; whereas in the caldCL1 cell line (Fig. 1(b)) these two proteins are less expressed. Thus, multiple genetic pathways can be taken in the progression to malignancy. The c-myc is an important oncogene that may be important 
in the development of tumors. However, alternative oncogenes or other factors may provide alternative mechanisms for carcinogenesis in these breast cancer cell lines. In both cell lines the overexpression of p53 and c-src still remain as possible biomarkers for the detection and prognosis of these types of tumor.

In conclusion, NP-RP-HPLC provides a rapid method for separation of proteins from whole cell lysates of cancer cell lines. This method can be used with MALDI-TOF mass spectral analysis to identify highly expressed proteins, which are biomarkers for carcinogenesis. These proteins include the important tumor suppressor p53 and well-known oncogenes such as c-src, c-myc, h-ras and related proteins. It has been shown that there are large differences in the expression of p53 and c-src between the normal (immortalized) breast epithelial cell line and the fully malignant species. Further, there are salient differences in the expression of different oncogenes between the two related breast cancer cell lines studied. The presence of p53 and these key oncogenes may serve as important biomarkers for detection and prognosis of tumors in future studies.

\section{Acknowledgements}

We gratefully acknowledge partial support of this work by the National Science Foundation Grant \#DEB9120006 to the Center of Microbial Ecology at Michigan State University and the National Institutes of Health under Grant \#R01GM49500. We also thank Dr. Tim Barder of MICRA Scientific, Inc. for generously providing the non-porous HPLC columns.

\section{REFERENCES}

1. O'Farrell PH, J. Biol. Chem. 1995; 250: 4007.

2. Patterson SD, Aebersold R, Electrophoresis 1995; 16: 1791.

3. Niedhardt FC, Appleby DB, Sankar P, Hutton ME, Phillips TA, Electrophoresis 1989; 10: 116.

4. Anderson NL, Esquer-Blasco R, Hofmann JP, Anderson NG, Electrophoresis 1991; 12: 907.

5. Strahler JR, Kuick R, Hanash SM. Two-Dimensional Electrophoresis, In Protein Structure. A Practical Approach. Creighton T (ed). IRL Press, 1989; 231-266.

6. Jensen PJ, Pasa-Tolic L, Anderson GA, Horner JA, Lipton MS, Bruce JE, Smith RD, Anal. Chem. 1999; 71: 2076.

7. Opitek GJ, Ramirez SM, Jorgenson JW, Moseley MA, Anal. Biochem. 1998; 258: 349 .

8. Opitek GJ, Lewis KC, Jorgenson JW, Anal. Chem. 1997; 69: 1518.

9. Chong BE, Lubman DM, Rosenspire A, Miller F, Rapid Commun. Mass Spectrom. 1998; 12: 1986.

10. Chen Y, Wall D, Lubman DM, Rapid Commun. Mass Spectrom. 1998; 12: 1994.

11. Dai Y, Li L, Roser DC, Long SR, Rapid Commun. Mass Spectrom. 1999; 13: 73 .

12. Nilsson CL, Murphy CM, Ekman R, Rapid Commun. Mass Spectrom. 1997; 11: 610.
13. Nilsson CL, Puchades M, Westman A, Blennow K, Davidsson P Electrophoresis, 1999; 20: 860

14. Krishnamurthy T, Davis MT, Stahl DC, Lee TD, Rapid Commun. Mass Spectrom. 1999; 13: 39.

15. Davidsson P, Westman A, Puchades M, Nilsson CL, Blennow K, Anal. Chem. 1999; 71: 642.

16. Wall DB, Lubman DM, Flynn SJ, Anal. Chem. 1999; in press.

17. Soule HD, Maloney TM, Wolman SR, Peterson WDJ, Brenz R, McGrath CM, Russo J, Pauley RJ, Jones RF, Brooks SC, Cancer Res. 1990; 50: 6075.

18. Mercer WE, Amin M, Sauve GJ, Appella E, Ullrich SJ, Roman JW, Oncogene, 1990; 5: 973.

19. Lane DP, Benchimol S, Genes Dev., 1990; 4: 1.

20. Levine AJ, Momand J, Findlay CA, Nature, 1991; 351: 453.

21. Caron de Fromentel C, Soussi T, Genes Chrom. Cancer, 1992; 3. 202.

22. Bertheau P, Steinberg SM, Merino MJ, Human Pathology, 1998; 29: 323

23. Molina R, Segui MA, Climent MA, Bellmunt J, Albanelli J, Fernandex M, Filella X, Jo J, Gimenez N, Iglesias E, Miralles M, Alonso C, Peiro G, Perez-Picanol E, Ballesta AM, Anticancer Res. 1998; 18: 507.

24. Thompson AM, Anderson TJ, Condie A, Prosser J, Chetty U, Carter DC, Evans HJ, Steel CM, Int. J. Cancer, 1992; 50: 528.

25. Thompson AM, Steel CM, Chetty U, Hawkins RA, Miller WR, Carter DC, Forrest APM, Evans HJ, Brit. J. Cancer, 1990; 61: 74.

26. Harlozinska A, Bar JK, Tumor Biol., 1994; 15: 223.

27. Biscardi JS, Belsches AP, Parsons SJ, Molecular Carcinogenesis 1998; 21: 261.

28. Sheffield LG, Biochem. Biophys. Res. Commun. 1998; 250: 27.

29. Verbeek BS, Vroom TM, Adriaansen-Slot SS, Ottenhoff-Kalff AE, Geertzema JGN, Hennipman A, Rijksen G, J. Pathol. 1996; 180: 383.

30. Muller WJ, Cancer Met. Rev. 1991; 10: 217.

31. Ryan JJ, Prochownik E, Gottlieb CA, Apel IJ, Merino R, Nunez G, Clarke MF, Proc. Natl. Acad. Sci. USA 1994; 91: 5878.

32. Krajewski S, Tanaka S, Takayama S, Schibler MJ, Fenton W, Reed JC, Cancer Res. 1993; 53: 4701.

33. Prendergast GC, Lawe D, Ziff EB, Cell 1991; 65: 395.

34. Santner SJ, Miller FR, Dawson PJ, Tait L, Soule HD, Eliason J, Heppner GH, Proc. Am. Assoc. Cancer Res. 1998; 39: 202.

35. Whittal RM, Li L, Anal. Chem. 1995; 67: 1950.

36. Bai J, Liu YH, Cain TC, Lubman DM, Anal. Chem. 1994; 66: 3423.

37. Zhu YD, He L, Srinivasan J, Lubman DM, Rapid Commun. Mass Spectrom. 1997; 11: 987.

38. Whittal RM, Russon LM, Weinberger SR, Li L, Anal. Chem. 1997; 69: 2147.

39. Colby SM, Reilly JP, Anal. Chem. 1996; 68: 1419.

40. Schürenberg M, Schulz T, Dreisewerd K, Hillenkamp F, Rapid Commun. Mass Spectrom. 1996; 10: 1873.

41. Brown RS, Lennon JJ, Anal. Chem. 1995; 67: 1998.

42. Available: http://prospector.ucsf.edu

43. Barbareschi M, Appl. Immnohistochem. 1996; 4: 106.

44. MacGrogan G, Bonichon F, de Mascarel I, Trojani M, Durand M, Avril A, Coindre JM, Breast Cancer Res. Treat 1995; 36: 71.

45. Barnes DM, Dublin EA, Fisher CJ, Levison DA, Millis RR, Hum. Pathol. 1993; 24: 469. 